\title{
Bilateral inferior petrosal sinus sampling
}

\author{
Benedetta Zampetti', Erika Grossrubatscher', Paolo Dalino Ciaramella', \\ Edoardo Boccardi ${ }^{2}$ and Paola Loli ${ }^{1}$
}

${ }^{1}$ Department of Endocrinology, Ospedale Niguarda, Milano, Italy ${ }^{2}$ Department of Neuroradiology, Ospedale Niguarda, Milano, Italy
Endocrine CONNECTIONS

\begin{abstract}
Simultaneous bilateral inferior petrosal sinus sampling (BIPSS) plays a crucial role in the diagnostic work-up of Cushing's syndrome. It is the most accurate procedure in the differential diagnosis of hypercortisolism of pituitary or ectopic origin, as compared with clinical, biochemical and imaging analyses, with a sensitivity and specificity of $88-100 \%$ and $67-100 \%$, respectively. In the setting of hypercortisolemia, ACTH levels obtained from venous drainage of the pituitary are expected to be higher than the levels of peripheral blood, thus suggesting pituitary ACTH excess as the cause of hypercortisolism. Direct stimulation of the pituitary corticotroph with corticotrophin-releasing hormone enhances the sensitivity of the procedure. The procedure must be undertaken in the presence of hypercortisolemia, which suppresses both the basal and stimulated secretory activity of normal corticotrophic cells: ACTH measured in the sinus is, therefore, the result of the secretory activity of the tumor tissue. The poor accuracy in lateralization of BIPSS (positive predictive value of $50-70 \%$ ) makes interpetrosal ACTH gradient alone not sufficient for the localization of the tumor. An accurate exploration of the gland is recommended if a tumor is not found in the predicted area. Despite the fact that BIPSS is an invasive procedure, the occurrence of adverse events is extremely rare, particularly if it is performed by experienced operators in referral centres.
\end{abstract}

Correspondence should be addressed to P Loli or B Zampetti Email

paola.loli@ospedaleniguarda. it or benedettazampetti@ yahoo.it

\section{Introduction}

The differentiation among different causes of ACTHdependent hypercortisolism is crucial to establish a proper treatment for this condition; the minority of patients with ectopic ACTH secretion (EAS) must be distinguished from the much larger population of patients with pituitary-dependent ACTH hypersecretion. The need for an effective distinction comes from the observation that (more frequently than previously believed) tumorssecreting ACTH ectopically cause a syndrome, which is often clinically and biochemically indistinguishable from a syndrome of pituitary origin. Many of these tumors (particularly bronchial carcinoids) remain occult to the specific imaging techniques for many years. In this context, the diagnostic accuracy of the stimulatory and inhibitory hormone tests is suboptimal: $65-100 \%$ sensitivity and 60-100\% specificity for the high-dose dexamethasone test and 70-93\% sensitivity and 95-100\% specificity for the CRH test $(1,2,3,4,5,6,7,8,9,10,11)$.

In the authors' experience, 4 out of 11 patients with EAS showed cortisol suppression after high-dose dexamethasone and 3 out of 12 showed ACTH and/or cortisol response to $\mathrm{CRH}$ stimulation according to current response criteria. The use of more stringent criteria to define responsiveness to the diagnostic tests increases
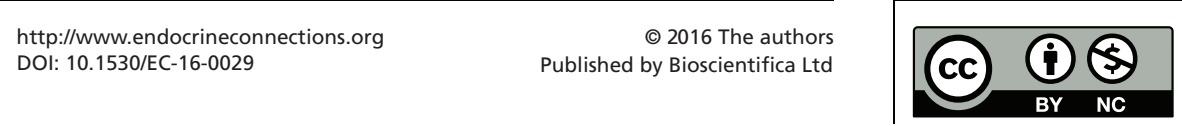
the ability to differentiate Cushing's disease (CD) from EAS, but invariably leads to reduced diagnostic sensitivity (12). On the other hand, dynamic gadolinium-enhanced MRI of the pituitary with specific protocols (which represents the most accurate imaging modality) still has limited power in identifying subcentimeter ACTHsecreting microadenomas and, in addition, it identifies $10-20 \%$ of nonfunctioning pituitary incidentalomas. For these reasons, MRI cannot be completely relied upon to differentiate between a pituitary and an ectopic origin of ACTH hypersecretion $(13,14,15)$. Although the evidence of a pituitary macroadenoma $(>10 \mathrm{~mm})$ in the diagnostic work-up for ACTH-dependent hypercortisolism is highly suggestive of pituitary disease, this is not true for smaller lesions that still might be incidentaloma $(16,17)$. The Consensus Statement on Diagnosis and Complications of Cushing's Syndrome suggests $6 \mathrm{~mm}$ as a reasonable cut-off for a pituitary lesion detected by MRI to be considered a corticotroph adenoma, providing a definitive diagnosis and not requiring further evaluation in the presence of dynamic biochemical studies compatible with CD (18); however, there is no universal agreement on this size cut-off nor on the more appropriate size of a pituitary lesion that could allow a corticotroph adenoma and an incidentaloma to be distinguished from each other $(19,20,21)$. The accuracy of the $6 \mathrm{~mm}$ tumor size cut-off value in the differentiation between patients with $\mathrm{CD}$ and EAS has been recently evaluated by Yogi-Morren and coworkers in 104 and 26 patients, respectively, providing $96 \%$ specificity for the diagnosis of CD (22).

\section{Historical review}

Inferior petrosal sinus sampling (IPSS) as a diagnostic tool in the differential diagnosis between pituitarydependent and ectopic ACTH syndrome was established in the 1970s $(1,23,24,25)$. The determination of ACTH levels in the jugular vein had been previously attempted $(26,27,28)$; however, the risk of the dilution of jugular vein blood by multiple venous affluents limited its common clinical use. The procedure of IPSS was for the first time performed in one patient with Cushing's syndrome, by selective and bilateral (not simultaneous) catheterization via a transjugular approach (29). Subsequently, IPSS was performed first by an unilateral approach $(30,31$, $32,33)$ to differentiate pituitary from ectopic ACTH oversecretion, then by bilateral and simultaneous catheterization, for lateralization of ACTH-secreting adenomas within the pituitary (34). Later, Oldfield and
(C) 2016 The authors

http.//WWw.endocrineconnections.org DOI: 10.1530/EC-16-0029 coworkers in 1985 confirmed the usefulness of bilateral simultaneous sampling of inferior petrosal sinuses (BIPSS) in localizing the ACTH-secreting microadenoma in one side of pituitary gland, and showed the effectiveness of hemihypophysectomy on the side with the highest ACTH concentrations in three patients without pathological evidence of microadenoma (35). The procedure has been subsequently further improved by direct stimulation of the pituitary corticotroph with corticotropin-releasing hormone (CRH), which was initially used during BIPSS to improve the lateralization of ACTH-secreting pituitary microadenomas $(36,37,38)$.

The importance of the additional use of CRH during IPSS to enhance the sensitivity of the procedure in the differentiation between eutopic and ectopic Cushing's syndrome was established by an extensive review of the NIH experience (39).

\section{Rationale of BIPSS}

In the setting of hypercortisolemia, the procedure is performed to differentiate a pituitary from an ectopic source of ACTH. ACTH is expected to be found at a higher concentration close to the gland with respect to distant location where admixture with blood from the systemic circulation occurs; the higher concentration of ACTH near the pituitary suggests pituitary ACTH excess as the cause of hypercortisolism.

The suppression of normal corticotrophs by the longstanding hypercortisolemia is crucial for the diagnostic accuracy of BIPSS, because it ensures that any ACTH measured is secreted by tumor tissue (pituitary or ectopic).

\section{Use of CRH}

As ACTH secretion is intermittent and blood sampling during a nadir of ACTH between two secretory episodes might result in a false-negative ratio between central and peripheral ACTH concentration (IPS/P ratio), the procedure is undertaken under CRH stimulation in order to increase the diagnostic sensitivity (Table 1).

\section{Pitfalls to avoid}

It has been shown that blood from the anterior lobe of the pituitary remains lateralized as it flows into the inferior petrosal sinuses (40). It has also been suggested 
Table 1 Petrosal sinus sampling: summary of published results.

\begin{tabular}{|c|c|c|c|c|c|c|c|c|}
\hline & & $\begin{array}{c}\text { Patients/ } \\
\text { successful BIPSS }\end{array}$ & CD/EAS & CRH used & $\begin{array}{c}\text { Sensitivity } \\
\text { (without CRH) } \\
(\%)\end{array}$ & $\begin{array}{c}\text { Sensitivity } \\
\text { (with CRH) } \\
(\%)\end{array}$ & $\begin{array}{c}\text { Specificity } \\
\text { (without CRH) } \\
(\%)\end{array}$ & $\begin{array}{c}\text { Specificity } \\
\text { (with CRH) } \\
(\%)\end{array}$ \\
\hline Landolt (36) & 1986 & $8 / 8$ & $7 / 1$ & 8 & 71.0 & 100.0 & & 100 \\
\hline Vignati (83) & 1989 & $8 / 8$ & $8 / 0$ & 8 & & 100 & & \\
\hline Oldfield (39) & 1991 & $281 / 278$ & $215 / 20$ & 262 & 95.0 & 100.0 & 100 & 100 \\
\hline Findling $(46)^{\S}$ & 1991 & $29 / 27$ & $20 / 9$ & 24 & 100.0 & 100.0 & 100 & 100 \\
\hline Zarrilli (64) & 1995 & $22 / 26$ & $21 / 3$ & & 67.0 & 90.0 & & 100 \\
\hline Lopez (60) & 1996 & $32 / 30$ & $32 / 0$ & 24 & 90.0 & 92.0 & & \\
\hline Kaltsas $(19)^{\S}$ & 1999 & $128 / 86$ & $107 / 6$ & 124 & 72.5 & 97.0 & 100 & 100 \\
\hline Bonelli (62) & 2000 & $92 / 82$ & $63 / 9$ & 92 & 92.2 & 92.2 & 100 & 90 \\
\hline Colao (58) & 2001 & $97 / 97$ & $74 / 10$ & 78 & 85.0 & 88.0 & 90 & 100 \\
\hline Swearingen (63) & 2004 & $179 / 143$ & $139 / 10$ & 120 & 85.0 & 90.0 & 67 & 67 \\
\hline Liu (92) & 2004 & $95 / 95$ & $67 / 11$ & 30 & 93.0 & 95.0 & 100 & 100 \\
\hline Ilias (69) & 2005 & 67 & $0 / 67$ & & & & & 99 \\
\hline Machado (81) & 2007 & $56 / 56$ & $50 / 5$ & $56 *$ & 78.0 & $92.1 *$ & & $100 *$ \\
\hline Castinetti $(80)^{\S}$ & 2007 & $43 / 42$ & $36 / 7$ & $43 *$ & 86.0 & $97 *$ & 85 & $100 *$ \\
\hline Tsagarakis $(79)^{\S}$ & 2007 & 54 & $47 / 7$ & $54 * *$ & 61.7 & $97.9 * *$ & 100 & $100 * *$ \\
\hline $\operatorname{Lin}(86)$ & 2007 & $18 / 18$ & $18 / 0$ & 18 & 89 & 94 & & \\
\hline Jehle (65) & 2008 & $105 / 102$ & $105 / 0$ & 105 & & 98.0 & & \\
\hline Shi (88) & 2011 & $69 / 69$ & $64 / 5$ & & 90 & & 100 & \\
\hline Mulligan (75) & 2011 & $41 / 37$ & $35 / 1$ & 41 & & 94 & & 50 \\
\hline Andereggen (57) & 2012 & $23 / 23$ & $21 / 2$ & 23 & 81 & 90 & 66.7 & 66.7 \\
\hline Sheth (21) & 2012 & $283 / 237$ & $205 / 10$ & 180 & & $94 * * *$ & & $50 * * *$ \\
\hline Grant (66) & 2012 & $83 / 83$ & $72 / 10$ & 83 & & 93.0 & & 100 \\
\hline Wind (102) & 2013 & $501 / 496$ & $501 / 0$ & 499 & & 98.0 & & \\
\hline Deipolyi (67) & 2016 & $327 / 291$ & $182 / 17^{\circ}$ & $222 * * * *$ & $94 * * * *$ & 96 & & \\
\hline Authors' series & 2016 & $89 / 89$ & $65 / 8$ & 73 & 83 & 91 & 100 & 100 \\
\hline
\end{tabular}

${ }^{\S}$ Basal and stimulated ratio $>2$. *Stimulation with desmopressin. $* *$ Stimulation with $\mathrm{CRH}+$ desmopressin. $* * *$ Not known if procedures were done with or without use of $\mathrm{CRH}$. ${ }^{* * *}$ Not known if procedures were done with $\mathrm{CRH}$ or desmopressin. ${ }^{\circ}$ None pathologically confirmed.

that each single patient could have a dominant petrosal sinus that contains a much higher percentage of the total pituitary ACTH (41). The reason for this side dominance remains unclear, but similar patterns of preferential unilateral venous drainage can be found in other venous sinuses of the brain (42). As a consequence, in order to correctly predict the source of excess ACTH, blood samples must be taken from both inferior petrosal sinuses in order to avoid the risk of an incorrect identification of the side containing the higher ACTH concentration, and therefore make an erroneous diagnosis of EAS. The simultaneous sampling of both inferior petrosal sinuses overcomes the risk of sampling blood during different episodes of ACTH secretion and allows comparison between the sides of the pituitary in the attempt to localize the ACTH-secreting tumor within the gland (see 'BIPSS and corticotroph microadenoma lateralization'). Suppression of normal corticotroph function by sustained hypercortisolism is crucial to avoid false positives; in fact, a central-to-peripheral ACTH gradient, identical to the gradient seen in pituitary Cushing's, may occur in patients within active phase of cyclical hypercortisolism, previous medical treatment or pseudo-Cushing state (41). In line with this observation, the procedure should be reserved to patients with clear biochemical evidence of ACTH-dependent hypercortisolism (i.e. the diagnosis of Cushing's syndrome must be established before performing BIPSS) and who are hypercortisolemic at the time of the procedure. It is our practice to collect a 24-h urinary sample for cortisol determination the day before the procedure to evaluate ex post its diagnostic accuracy; other clinicians share our policy or determine late-night salivary cortisol measurement performed immediately before the test $(43,44)$. Instead of obtaining 24 -h UFC the day before the procedure, some suggest measuring serum cortisol level in the morning of the procedure of BIPSS or during the procedure (stat cortisol) to postpone it in case of normal/low cortisol concentration.

After bilateral adrenalectomy, the interpretation of BIPSS is difficult in the case of both the pituitary microadenoma and an ectopic source of ACTH, as normal corticotrophs are no longer suppressed and the level of plasma ACTH is elevated in comparison with peripheral values (41).

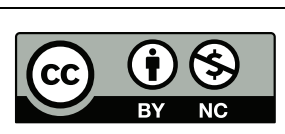
This work is licensed under a Creative Commons
Attribution-NonCommercial 4.0 International License. 


\section{Indications for BIPSS}

The indication for BIPSS differs among clinicians; some suggest that BIPSS should be reserved to patients with clinical and biochemical evidence of $\mathrm{CD}$ and negative or equivocal MRI findings (45), whereas others recommend BIPSS for patients with equivocal responses to hormone test or in cases of discrepancies between biochemistry and imaging findings (18). Still others recommend BIPSS as a routine investigation in any patient with proven ACTH-dependent Cushing's syndrome $(25,46)$.

An additional reason to perform BIPSS is persistence of Cushing's syndrome after previous unsuccessful pituitary surgery, to ensure that the diagnosis of CD is correct.

Although the use of tracers or the composite positron emission tomography/MRI imaging might improve the delineation of Cushing microadenomas and increase their detectability, only $50-60 \%$ of patients with CD have shown evidence of a pituitary adenoma at MRI, less than the pretest probability of having the disease $(17,47)$. Performing BIPSS in any patient with negative MRI results may, therefore, lead to redundant investigations in many cases. Obviously, this is an area of controversy reflecting differences in practice even in centres of excellence.

In the authors' opinion, the need for performing BIPSS should be based on the response to the hormone tests and in particular to the CRH test. Previous data and the authors' experience have shown that an increase $>50 \%$ in ACTH and $>30 \%$ in cortisol has a very high specificity
(90-100\%) to potentially rule out the presence of EAS $(8,48)$. In this way, the diagnosis of EAS might be missed in the very rare occurrence of patients with CRH-secreting ectopic tumors that mimic CD $(21,49,50)$. Other data refute the use of CRH (51).

The diagnostic accuracy of high-dose dexamethasone test (sensitivity $65-100 \%$, specificity $60-100 \%$ ) is lower than the CRH test $(9,48,52)$ and the usefulness of the test has been challenged (11). The diagnostic yield of the procedure in the subgroup of patients with Cushing's syndrome and equivocal response to hormone tests has been questioned by Jeffcoate (53). A retrospective evaluation of BIPSS in a subgroup of patients with these characteristics showed a slightly worse performance than in the whole population of patients with ACTHdependent Cushing's syndrome (54). This issue has not been prospectively and specifically addressed so far and it cannot be matched with the authors' experience.

In the authors' opinion, BIPSS should be performed in all patients with an $\mathrm{ACTH} /$ cortisol response to the CRH test not consistent with CD, independently from the response to the high-dose dexamethasone suppression test, unless MRI finding shows clear evidence of pituitary adenoma $(>6 \mathrm{~mm})$; on the other hand, in case of positive response to the $\mathrm{CRH}$ test, especially in case of a consistent response to the dexamethasone test, BIPSS should not be performed, even in the absence of MRI evidence of pituitary adenoma (Fig. 1). This could be an area of controversy and discussion, and reports of results from large series may resolve these eventually.

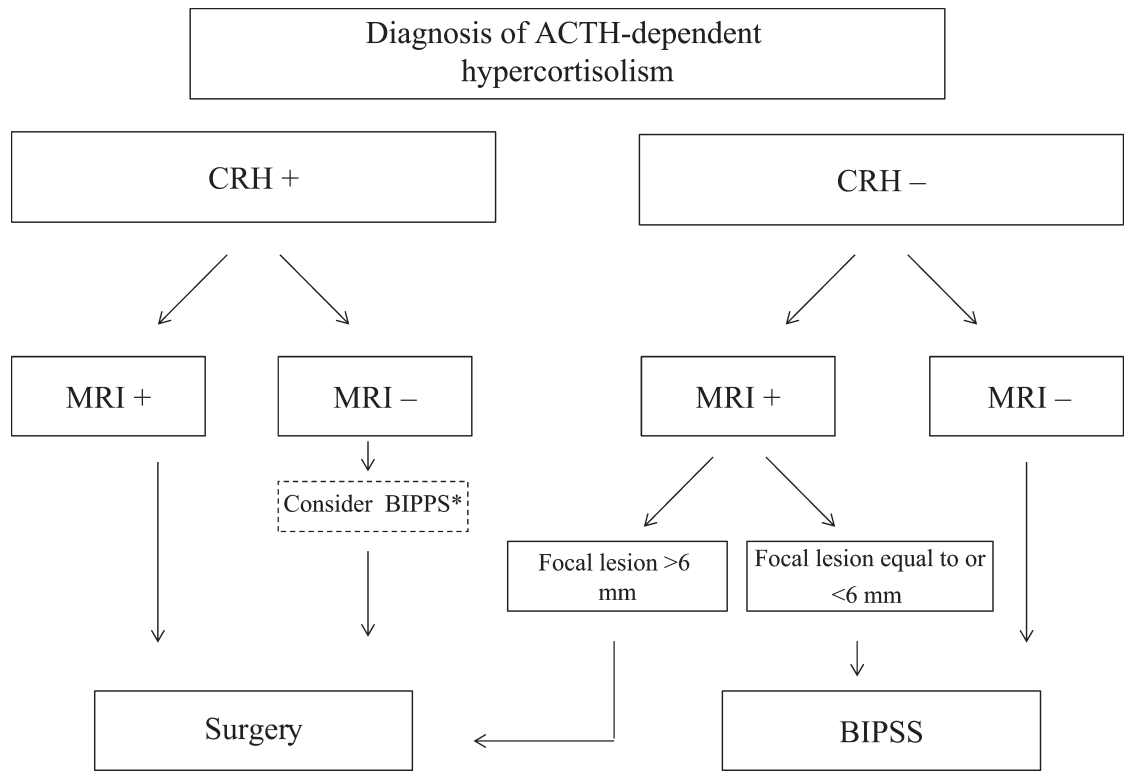

Figure 1

Algorithm representing authors' current practice on the indication for BIPPS. $\mathrm{CRH}+$ : positive response to $\mathrm{CRH}$ stimulation test defined as an increment $\geq 30 \%$ of serum cortisol over baseline or $\geq 50 \%$ or more of plasma ACTH over baseline. $\mathrm{CRH}-$ : negative response to $\mathrm{CRH}$ stimulation test defined as an increment $<30 \%$ of serum cortisol over baseline or $<50 \%$ of plasma ACTH over baseline. *Use of BIPPS controversial, see text. 


\section{Venous anatomy}

Understanding the venous anatomy is crucial to the success of the procedure as anatomic variants affect catheterization as well as interpretation of results. Blood from the anterior lobe of the pituitary flows through small hypophyseal veins into a network of veins overlying the pituitary surface, which drains laterally into the cavernous sinuses, and from here into the inferior petrosal sinuses, which course posteriorly and caudally and enter the jugular bulb at the skull base (40).

Anatomic variants may cause venous drainage from the cavernous sinus to follow pathways different from those expected, i.e. an anastomosis to the vertebral venous plexus before draining into the jugular vein, no connection between inferior petrosal sinus and jugular vein (55), an hypoplastic or plexiform inferior petrosal sinus. As reported previously, a catheter inserted into an hypoplastic or plexiform sinus might appear appropriately positioned, but at the same time cause altered venous drainage causing an obstruction (56).

In their review on 501 procedures, Doppman and coworkers reported four patients with negative petrosal sinus sampling in the presence of surgically proven $\mathrm{CD}$ due to a hypoplastic or plexiform inferior petrosal sinus on the side of the microadenoma (56). The use of microcatheters during the procedure reportedly may allow a normal blood flow in asymmetric drainages (57).

Direct sampling from the cavernous sinus might possibly compensate for the problems due to an atrophic or plexiform inferior petrosal sinus.

By reviewing the retrograde inferior petrosal sinograms of 100 consecutive patients with ACTHdependent Cushing's syndrome, Doppman and coworkers reported that $75 \%$ had large, bilaterally symmetrical inferior petrosal sinuses, $18 \%$ had asymmetrical inferior petrosal sinuses with one smaller than the contralateral and in $7 \%$, the petrosal sinuses were bilaterally small (56). As the prevalence of abnormalities is greater than the prevalence of false-negative results, adequate catheterization can be considered as feasible in most cases.

It was suggested that the study of the pattern of venous drainage by complete venography of the basilar sinuses might be included within the interpretation of venous sampling data, particularly in the context of intersinus gradient of ACTH determination for localization of the pituitary adenoma. In the study by Mamelak and coworkers, the symmetric or asymmetric pattern of venous drainage in the cavernous and petrosal sinuses helped in the interpretation of the lateralization gradients (42).

In the authors' institution, a venous angiography is always performed bilaterally, allowing one to confirm the correct positioning of the catheters.

\section{Procedure}

The procedure must be undertaken by experienced interventional neuroradiologists with a team of trained operators; in these conditions, successful bilateral sampling is usually achieved in more than $90 \%$ of cases. It has been reported that the success rate increases with the level of expertise of the operator depending on the number of procedures carried out (19). The procedure takes 60-90 min (depending on the complexity of sinus catheterization) to be completed when ACTH sampling after CRH stimulation is included.

Informed written consent must be obtained from the patient before the procedure. A conscious sedation (diazepam) is maintained to assess the patient's condition.

Systemic anticoagulation is not necessary after vascular access; in the authors' experience, it should not be induced. When used, heparin is given as an i.v. bolus injection after vascular access has been obtained (e.g. 3500 IU heparin) (19).

Through a percutaneous bilateral approach, catheters are inserted into the femoral vein and are advanced to the petrosal sinuses under fluoroscopic guidance; the most useful catheter is a $4-5$-French catheter with a slightly angulated tip $\left(30^{\circ}-45^{\circ}\right)$.

In order to verify proper catheter placement and venous drainage, digital subtraction venography should be performed before and after the sampling. (In the authors' institution, final venography is performed between $10^{\prime}$ and $15^{\prime}$ sampling.) Once catheters are properly placed, two sets of blood samples for basal ACTH determination are slowly withdrawn simultaneously from each petrosal sinus and a peripheral vein. In the author's approach, after obtaining basal samples, intravenous injection of $\mathrm{CRH}$ ( $100 \mathrm{mcg}$ or $1 \mathrm{mcg} / \mathrm{Kg}$ bw) is administered as bolus, and poststimulation samples are obtained at $1^{\prime}, 3^{\prime}, 5^{\prime}, 10^{\prime}$ and $15^{\prime}$. All samples are immediately collected in prechilled tubes containing EDTA kept on ice until centrifugation; centrifugation and plasma separation of blood samples should be performed within an hour and plasma samples frozen until ACTH assay. Patients then should rest in bed for $2-4 \mathrm{~h}$ after sampling. http://www.endocrineconnections.org
DOI: 10.1530/EC-16-0029
(C) 2016 The authors Published by Bioscientifica Ltd
This work is licensed under a Creative Commons Attribution-NonCommercial 4.0 International License. 
No difference in the accuracy of BIPSS has been noted when ovine or human CRH is used (19).

\section{Diagnostic criteria}

ACTH values are used to calculate the ratio of the concentration in the right or left inferior petrosal sinus to the concentration in the peripheral blood (IPS/P ratio) in each set of samples; then, the highest ratio is identified.

According to the criteria established in the seminal paper by Oldfield (39), a central-to-peripheral ACTH maximal ratio $\geq 2$ in basal conditions and $\geq 3$ at any time point after CRH stimulation is strongly suggestive of pituitary secretion, i.e. CD (conventionally: positive test). If these thresholds are not met, a peripheral (ectopic) source of ACTH is presumed (conventionally: negative test). Figure 2 shows examples of BIPSS results from authors' series.

Slightly different IPS/P ratios have been identified in other centres as adequately discriminating ectopic from eutopic ACTH secretion $(19,58)$. Based on the reports of patients with EAS with IPS/P ratio up to 1.7, it was suggested that more stringent criteria should be adopted (59).

The ratio of the ACTH concentrations between the two inferior petrosal sinuses (intersinus gradient) indicates lateralization of ACTH secretion. According to Oldfield (35), an intersinus ratio $\geq 1.4$ in basal conditions is predictive of the localization of the adenoma within the side of the pituitary with the highest concentration.

Subsequently, intersinus gradients of ACTH recorded after $\mathrm{CRH}$ stimulation have also been considered for lateralization of the pituitary microadenoma, although it was previously shown that the positive predictive value of the test for lateralization of a microadenoma is not improved by sampling after CRH stimulation, with respect to basal sampling (39).

\section{Diagnostic accuracy of BIPSS}

The accuracy of BIPSS in the differential diagnosis of CD was demonstrated in a large series of 281 patients; $95 \%$ of patients with pituitary-dependent CD were distinguished from those with nonpituitary Cushing's syndrome in basal samples when the maximal IPS/P ratio was $\geq 2$ and $100 \%$ of patients after CRH stimulation when the IPS/P ratio was $\geq 3$; by contrast, all patients with EAS showed central-to-peripheral ratio $<2$ in basal samples and $<2.3$ after stimulation.

Note that patients with EAS could show an increase in sinus ACTH after CRH stimulation, although there was no significant change in peripheral blood ACTH levels during the same interval (39).

With broadened experience with BIPSS, it clearly appears that the actual accuracy of BIPSS in clinical practice is lower than expected; both false-negative $(19,60,61,62,63,64,65,66,67)$ and, less commonly, false-positive results have been reported $(68,69,70)$.

Overall, the sensitivity and specificity of the procedure range from 88 to $100 \%$ and from 67 to $100 \%$, respectively (Table 1).

The possible determinants of reduced BIPSS performance are as follows:

1. Technical/anatomical: the rate of successful catheterization is $<100 \%$, and possible anatomical variants of the venous drainage from the pituitary may prevent catheterization.

2. Patient/disease dependent: in patients with cyclical or mild Cushing's disease, low or intermittent
A

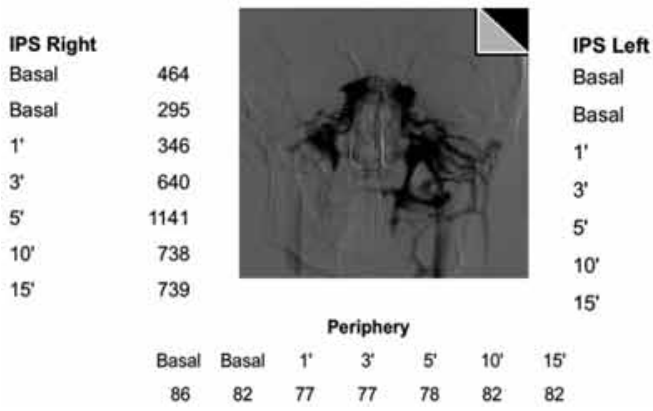

B

IPS Right
Basal
Basal
$1^{\prime}$
$3^{\circ}$
$5^{\prime}$
$10^{\prime}$
$15^{\prime}$
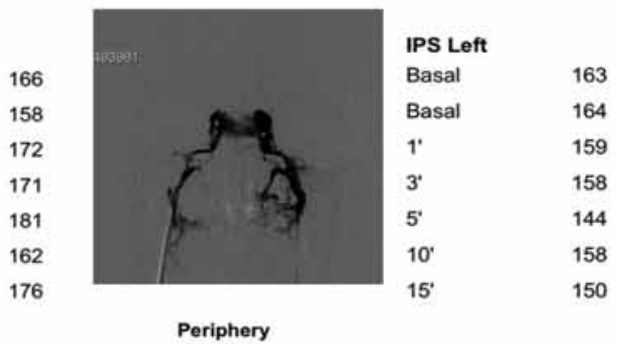

Basal Basal $v^{\prime} \quad 3^{*} 5^{\prime} \quad 10^{\circ} \quad 15^{\circ}$

$\begin{array}{lllllll}152 & 157 & 145 & 149 & 143 & 146 & 135\end{array}$

Figure 2

(A) Plasma ACTH concentration ( $\mathrm{pg} / \mathrm{mL}$ ) in a patient with final diagnosis of Cushing's disease (example of BIPSS data from the authors' series). (B) Plasma ACTH concentration $(\mathrm{pg} / \mathrm{mL})$ in a patient with final diagnosis of EAS due to bronchial carcinoid (example of BIPSS data from the authors' series).

http://www.endocrineconnections.org $\quad$ C 2016 The authors
$\begin{array}{lr}\text { DOI: } 10.1530 / \text { EC-16-0029 } & \text { Published by Bioscientifica Ltd }\end{array}$

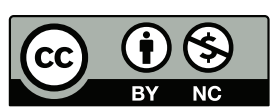

This work is licensed under a Creative Commons Attribution-NonCommercial 4.0 International License. 
Table 2 Causes of reduced BIPSS performance.

\begin{tabular}{l}
\hline False negative \\
\hline Cyclic or mild CD \\
Low responsiveness to \\
CRH stimulation of \\
corticotrophic tumor \\
Corticotrophic tumor \\
ectopically located in \\
sphenoidal sinus
\end{tabular}

False positive

Cyclic EAS

Cortisol-lowering treatment in EAS

Very low peripheral ACTH levels $\mathrm{CRH}$ producing ectopic tumors
ACTH production could prevent the production of a threshold IPS/P ratio; similarly, a pituitary tumor could be poorly responsive to $\mathrm{CRH}$ stimulation, and stimulation would not give rise to the expected IPS/P ratio (false negatives). On the contrary, an ectopic tumor with cyclical secretion of ACTH might incompletely suppress the secretory activity of normal corticotrophic cells allowing persistence of an IPS/P ratio, or in the case of an ectopic tumor the treatment with cortisol-lowering drugs might restore normal corticotrophic cells, which might respond to $\mathrm{CRH}$ stimulation and cause an adequate IPS/P ratio (false positives). The occurrences of concomitant ACTHCRH secretion by an ectopic tumor or of a corticotroph adenoma ectopically located in the sphenoid sinus are very rare causes of false-positive and false-negative BIPSS, respectively (71). Lastly, the occurrence of very low peripheral ACTH levels during BIPSS, such as those determined in the presence of a cortisol secreting adrenal lesion, could cause supra-threshold IPS/P ratios that are difficult to interpret $(21,63)$ (Table 2).

3. 'Procedural': a cause of reduced BIPSS performance is the a priori exclusion from calculation of sensitivity/ specificity of BIPSS of all patients that are not formally classifiable or those having IPSS results predictive of an ectopic source, in whom definite diagnosis is never obtained and who did not undergo pituitary exploration. A number of these cases could prove to be false negatives (21).

False-negative BIPSS results are more common than false positives and are generally interpreted as due to anatomical variants or technical reasons. The problem they pose involves the exposure of patients affected by pituitary disease to serial radiological and hormonal procedures in order to show an ectopic source of ACTH, and to palliative medical treatments or extreme surgical solutions such as bilateral adrenalectomy, based on the evidence that some ectopic ACTH-secreting tumors may remain occult for many years. On the other hand, patients are not or at a (c) 2016 The authors

http://www.endocrineconnections.org DOI: 10.1530/EC-16-0029 later stage offered a potentially curative surgical treatment such as pituitary adenomectomy.

Data suggest a prevalence of false negatives of $3-19 \%$, reported in series smaller than that from the NIH $(21,56,60)$.

Some studies had suggested that the measurement of other anterior pituitary hormones, in addition to ACTH, might be useful during BIPSS in the context of correct lateralization of a microadenoma or, more specifically, for correcting for dilution by nonpituitary blood during BIPSS (72).

In their retrospective analysis, Findling and coworkers showed that simultaneous measurement of PRL and ACTH is a reliable method for correcting for dilution by nonpituitary blood during BIPSS in Cushing's syndrome that may improve the diagnostic accuracy of the procedure by unmasking false-negative results (73).

In the authors' experience, the correction for PRL concentration simultaneously sampled in BIPSS and peripheral blood in addition to ACTH, in 29 patients with ascertained $\mathrm{CD}$ and 5 with EAS with ascertained tumor, allowed reclassification of 4 patients with pituitary-dependent disease and false-negative BIPSS. More recently, Sharma and coworkers $(74,75)$ confirmed that measurement of prolactin levels during BIPSS can increase accuracy when the ACTH IPS/P ratio suggests EAS. Although supported by a limited number of observations, prolactin determination during BIPSS is a useful tool; in the authors' experience, serum for prolactin determination should be stored during BIPSS and prolactin concentration should be determined in case of absence of gradient (76). According to two previous studies, an analysis of the peripheral ACTH response to $\mathrm{CRH}$ during BIPSS may be useful in the differentiation between false and true negatives, because a rise in peripheral ACTH was seen in false-negative but not in true-negative cases $(19,63)$. In the authors' experience, this observation cannot be confirmed, as an ACTH increase $>35 \%$ was recorded in peripheral blood from one of eight patients with EAS tested.

\section{Use of desmopressin during BIPSS}

Desmopressin stimulation in addition to CRH during BIPSS was proposed to increase the sensitivity of the test, with the aim to overcome the risk of false-negative results in patients with Cushing's disease who are poor responders to $\mathrm{CRH}$. The advantage of increasing the sensitivity of BIPSS by adding desmopressin to the stimulation with 
CRH must be balanced against the objective risk of an increase in false-positive responses in patients with EAS possibly due to the expression of the relatively selective desmopressin V2R subtype receptor in these tumors $(77,78)$, therefore compromising the specificity of the procedure. Data on this topic are contradictory (79).

The use of desmopressin alone during BIPSS has also been investigated due to unavailability of CRH in some centres.

Although on a limited number of patients, previous and more recent reports highlight the role of desmopressin as a safe and effective alternative to $\mathrm{CRH}(80,81,82)$.

Taking into account that the diagnostic criteria (basal and stimulated $\mathrm{C} / \mathrm{P}$ ratios) adopted for the use of DDAVP in BIPSS are different among the studies and based on a very limited number of patients with EAS, it can be concluded that larger confirmatory studies have to be performed before this procedure is adopted in the daily practice; at present, BIPSS with CRH remains the gold standard in the evaluation of CD.

\section{BIPSS and corticotroph microadenoma lateralization}

Due to the small size of ACTH-secreting adenomas and the clinical relevance of preoperative localization, it was hypothesized that BIPSS could help in localizing the adenoma within the pituitary. The ipsilateral drainage of the two sides of the pituitary and the proximity of sampling to the source of ACTH production would determine a gradient of concentration between the two sides, suggestive of the presence of the tumor on the side with the highest hormone concentration. Early studies investigating preoperative lateralization of BIPSS in patients with ACTH-secreting adenoma were performed on small series of cases, documenting 100\% accuracy (34, $35,36,83)$. According to Oldfield, an intersinus ratio $\geq 1.4$ in basal conditions was predictive of the localization of the adenoma within the side with the highest concentration in 10 patients with $\mathrm{CD}$ and a pituitary microadenoma (35). Some years later, Oldfield and coworkers extended their observations to a larger group of 281 patients and reported an accuracy of $68 \%$ during basal sampling and $71 \%$ after CRH stimulation (39), in contrast with their previous study. A similar reduction in the accuracy of lateralization was observed by Landolt when the initial evaluation was extended to a larger series (84). Differing from Oldfield, Landolt could observe an improvement in accuracy with the use of CRH stimulation.
(๔) 2016 The authors Published by Bioscientifica Ltd
Subsequently, several studies (most applying an intersinus ratio $>1.4$ ) revealed that diagnostic accuracy of BIPSS in predicting tumor lateralization was poorer than expected from previous studies, with a range from 50 to $70 \%$ of correct prediction $(25,59,60,62,85,86)$. No improvement after CRH administration was consistently reported. In some studies, the predictivity of BIPSS in the preoperative localization of the adenomas was compared with the imaging studies, with discordant results; some studies claimed a superiority of BIPSS $(19,87,88)$, whereas others found no differences or a better predictive power of imaging $(58,60,89)$.

In order to understand the limits of the procedure and improve its diagnostic accuracy, Mamelak and coworkers suggested that a complete venous angiography was performed during the procedure, which demonstrated that asymmetric patterns of pituitary venous drainage were responsible for incorrect lateralization (42).

The occurrence of reversal of lateralizing gradient after CRH stimulation has been repeatedly reported; when present, BIPSS is not reliable in localizing the side of adenoma $(81,90,91,92)$. Some studies had suggested that the measurement of other anterior pituitary hormones in addition to ACTH in the samples obtained during BIPSS might be useful in the prediction of correct lateralization of a microadenoma, allowing to normalize the side-to-side gradient of ACTH $(83,93,94,95)$. This hypothesis, based on the assumption that the hormones measured drained symmetrically in the two sides of the pituitary, was not consistently confirmed and conversely an intersinus, and central/peripheral gradient also for these hormones was repeatedly documented $(96,97,98,99)$. More recent reports on the use of PRL in addition to ACTH to correctly localize the pituitary adenoma site in $\mathrm{CD}$ have given conflicting result $(100,101)$.

The results of the prospective observational study carried out at NIH to evaluate the accuracy in lateralization of BIPSS on a large group of 501 consecutive patients with CD and pathological confirmation of ACTH-secreting adenoma were recently published; an interpetrosal ratio $>1.4$ had a positive predictive value of $69 \%$ for lateralization, inferior to that of MRI (86\%). In this series, asymmetric or anomalous inferior petrosal sinus anatomy at venography or cavernous sinus invasion were not associated with decreased lateralization accuracy, whereas predictivity of lateralization was associated with left-sided adenoma and consistent pre- and post-CRH intersinus gradient. In the authors' opinion, data from BIPSS should guide the surgical exploration in patients without http://www.endocrineconnections.org DOI: 10.1530/EC-16-0029
This work is licensed under a Creative Commons Attribution-NonCommercial 4.0 International License. 
radiological evidence of an adenoma without preventing an accurate exploration of the gland if a tumor were not found in the predicted area, due to limited accuracy of lateralization (102).

\section{BIPSS in children and adolescents}

Experience with BIPSS in children and adolescents is less extensive than in adults. However, it has been successfully applied in young patients with CD to confirm the diagnosis of pituitary-dependent disease and help to localize the microadenoma within the pituitary. The results of BIPSS gave high prediction of the site of the tumor with an accuracy of lateralization results after $\mathrm{CRH}$ of $91 \%$ in a small series of 11 paediatric patients (103).

In a larger series of 50 young patients, BIPSS was the best test for the differential diagnosis of ACTH-dependent Cushing's syndrome, with 100\% accuracy. Lateralization results predicted correctly the site of the adenoma in $76 \%$ of patients (104).

A subsequent study from the same institution on a larger number of young patients with CD could not confirm the reliability of BIPSS in the prediction of the site of the adenoma within the pituitary (105).

\section{Complications}

Petrosal sinus catheterization is an invasive procedure which can be complicated, albeit rarely, by severe adverse events. In clinical practice, the most common minor adverse event is groin hematoma, reported in $4 \%$ of patients. Very severe adverse events have a prevalence much lower than $1 \%$.

Two occurrences of brainstem injury during BIPSS have been reported from the centre with the largest experience so far and two others were avoided. In no cases, the cause of the event was established, but it was hypothesized that microcatheters might increase the risk of entering anomalous petrosal sinus-to-brainstem bridging veins, thereby causing rupture or obstruction and increasing the risk of cerebellopontine injury or subarachnoid haemorrhage. It is suggested that neurological complications can be prevented if the patient is carefully monitored and the procedure is aborted at the earliest evidence of symptoms (106).

Two other cases of brainstem injury have been reported by two different centres: a stroke affecting the brainstem at the level of the pontocerebellar junction and a brainstem infarction; a venous variant leading to transient venous hypertension or thrombosis was suspected $(107,108)$.

One case of subarachnoid haemorrhage and one of deep venous thrombosis were reported by Bonelli and coworkers; the patient with venous subarachnoid haemorrhage experienced elevated arterial blood pressure, headache and confusion during the procedure (109).

One case of pulmonary embolism and a transient VI nerve palsy have also been reported $(110,111)$.

\section{Jugular vein sampling}

Jugular vein sampling (JVS) has been proposed as a safer and simpler alternative to BIPSS in the diagnosis of ACTHdependent hypercortisolism. Its accuracy was initially assessed in a cohort of ten patients (6 with CD and 4 with EAS), providing unsatisfactory results (32). Diagnostic performance was shown to be improved by the use of CRH stimulation and by positioning the catheter at a lower level of influx from petrosal sinuses, finding sensitivity for CD diagnosis of $80 \%$. In the same study, the authors compared JVS with BIPSS carried out on two separate days, and recommended the use of JVS, simpler and safer, reserving BIPSS to cases of negative JVS results (112).

These results were confirmed in a study where the two procedures were performed in the same session (sensitivity 81 and 94\%, respectively) (113). In a subsequent study, including 65 patients with CD and 13 patients with EAS, and using different central-to-peripheral ACTH cut-off values, Ilias and coworkers found, at 100\% specificity, a sensitivity for JVS of $83 \%$ and for BIPSS of $94 \%$ confirming the opportunity to perform JVS with CRH as a first-line invasive test reserving the use of BIPSS in cases of negative JVS results (114).

Overall, JVS is less invasive and adequately accurate to be first step procedure in institutions with limited BIPSS experience; in case of negative results, confirmatory BIPSS should be recommended.

\section{Cavernous sinus sampling}

Cavernous sinus sampling for ACTH determination has been proposed as an alternative to BIPSS to improve the diagnostic accuracy in the differential diagnosis between CD and EAS and in the intrasellar localization of the adenoma in view of the greater proximity of cavernous sinuses to pituitary and expected higher ACTH concentrations.

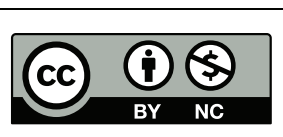

This work is licensed under a Creative Commons Attribution-NonCommercial 4.0 International License. 
Teramoto first introduced the procedure of selective venous sampling directly from cavernous sinus as an alternative to BIPSS, performing the procedure in a small series of patients and obtaining much greater central-to-peripheral ACTH gradients in comparison with BIPSS and a correct lateralization in all cases but one (115). Subsequent studies confirmed the utility of CSS with an accuracy in localizing the adenoma ranging from 82 to $91 \%$ with no complications $(116,117,118)$.

Less favourable results were also reported in terms of both differential diagnosis and lateralization accuracy with warning on the greater risk of adverse events $(42,119,120)$.

Overall, CSS has not entered the routine use among the invasive procedures, and BIPSS remains the investigation of choice.

\section{Conclusion}

BIPSS remains the best test to differentiate pituitary from ectopic ACTH-dependent Cushing's syndrome; although in clinical practice its accuracy is not $100 \%$, it presents very high specificity and better sensitivity than other biochemical tests.

It is an invasive procedure, but the occurrence of adverse events is extremely rare.

There are some conditions to be met in order to increase the accuracy of the test and minimize the risks.

BIPSS must be reserved to patients with clear clinical and biochemical evidence of sustained hypercortisolism, as the procedure does not reliably differentiate normal subjects or pseudo-Cushing states from patients with mild or episodic CD.

The diagnosis of ACTH-dependent Cushing's syndrome must be ascertained before BIPSS is performed and hypercortisolism near the time of catheterization documented.

It is mandatory that BIPSS be performed by experienced operators with ability to cannulate the inferior petrosal sinus; a careful analysis of pretest venogram is crucial, and a postsampling venography should confirm the correct positioning of the catheters. Close attention must be paid to handling of sampling.

\section{Declaration of interest}

The authors declare that there is no conflict of interest that could be perceived as prejudicing the impartiality of this review.

\section{Funding}

This research did not receive any specific grant from any funding agency in the public, commercial or not-for-profit sector.

\section{Acknowledgments}

We are indebted to Novartis Oncology for supporting the English language editing.

\section{References}

1 Crapo L. Cushing's syndrome: a review of diagnostic tests. Metabolism 197928 955-977. (doi:10.1016/0026-0495(79)90097-0)

2 Hermus AR, Pieters GF, Pesman GJ, Smals AG, Benraad TJ \& Kloppenborg PW. The corticotropin-releasing-hormone test vs. the high-dose dexamethasone test in the differential diagnosis of Cushing's syndrome. Lancet 19862 540-544. (doi:10.1016/s01406736(86)90113-3)

3 Howlett TA, Drury PL, Perry L, Doniach I, Rees LH \& Besser GM. Diagnosis and management of ACTH-dependent Cushing's syndrome: comparison of the features in ectopic and pituitary ACTH production. Clinical Endocrinology 198624 699-713. (doi:10.1111/j.1365-2265.1986.tb01667.x)

4 Grossman AB, Howlett TA, Perry L, Coy DH, Savage MO, Lavender P, Rees LH \& Besser GM. CRF in the differential diagnosis of Cushing's syndrome: a comparison with the dexamethasone suppression test. Clinical Endocrinology 198829 167-178. (doi:10.1111/j.1365-2265.1988.tb00258.x)

5 Flack MR, Oldfield EH, Cutler GB Jr, Zweig MH, Malley JD, Chrousos GP, Loriaux DL \& Nieman LK. Urine-free cortisol in the high-dose dexamethasone suppression test for the differential diagnosis of Cushing's syndrome. Annals of Internal Medicine 1992 116 211-217. (doi:10.7326/0003-4819-116-3-211)

6 Dichek HL, Nieman LK, Oldfield EH, Pass HI, Malley JD \& Cutler GB Jr. A comparison of the standard high dose dexamethasone suppression test and the overnight 8-mg dexamethasone suppression test for the differential diagnosis of adrenocorticotopin-dependent Cushing's syndrome. Journal of Clinical Endocrinology and Metabolism 199478 418-422. (doi:10.1210/jc.78.2.418)

7 Kaye TB \& Crapo L. The Cushing syndrome: an update on diagnostic tests. Annals of Internal Medicine 1990112 434-44. (doi:10.7326/0003-4819-76-3-112-6-434)

8 Nieman LK, Oldfield EH, Wesley R, Chrousos GP, Loriaux DL \& Cutler GB Jr. A simplified morning ovine corticotropinreleasing hormone stimulation test for the differential diagnosis of adrenocorticotropin-dependent Cushing's syndrome. Journal of Clinical Endocrinology and Metabolism 199377 1308-1312. (doi:10.1210/jc.77.5.1308)

9 Newell-Price J, Trainer P, Besser M \& Grossman A. The diagnosis and differential diagnosis of Cushing's syndrome and pseudo-Cushing's states. Endocrine Reviews 199819 647-672. (doi:10.1210/er.19.5.647)

10 Malchoff CD, Orth DN, Abboud C, Carney JA, Pairolero PC \& Carey RM. Ectopic ACTH syndrome caused by a bronchial carcinoid tumor responsive to dexamethasone, metyrapone, and corticotropinreleasing factor. American Journal of Medicine $1988 \mathbf{8 4}$ 760-764. (doi:10.1016/0002-9343(88)90116-7)

11 Aron DC, Raff H \& Findling JW. Effectiveness versus efficacy: the limited value in clinical practice of high dose dexamethasone suppression testing in the differential diagnosis of adrenocorticotropin-dependent Cushing's syndrome. Journal of Clinical Endocrinology and Metabolism 199782 1780-1785. (doi:10.1210/jc.82.6.1780)

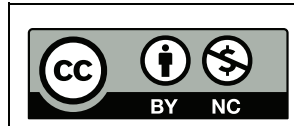

This work is licensed under a Creative Commons Attribution-NonCommercial 4.0 International License. 
12 Hermus AR, Pieters GF, Pesman GJ, Smals AG, Benraad TJ \& Kloppenborg PW. The corticotropin-releasing-hormone test vs. the high-dose dexamethasone test in the differential diagnosis of Cushing's syndrome. Lancet 19862 540-544. (doi:10.1016/s01406736(86)90113-3)

13 Nieman LK, Chrousos GP, Oldfield EH, Avgerinos PC, Cutler GB Jr \& Loriaux DL. The ovine corticotropin-releasing hormone stimulation test and the dexamethasone suppression test in the differential diagnosis of Cushing's syndrome. Annals of Internal Medicine 1986 105 862-867. (doi:10.7326/0003-4819-105-6-862)

14 Tabarin A, Laurent F, Catargi B, Olivier-Puel F, Lescene R, Berge J, Galli FS, Drouillard J, Roger P \& Guerin J. Comparative evaluation of conventional and dynamic magnetic resonance imaging of the pituitary gland for the diagnosis of Cushing's disease. Clinical Endocrinology 199849 293-300. (doi:10.1046/j.13652265.1998.00541.x)

15 Patronas N, Bulakbasi N, Stratakis CA, Lafferty A, Oldfield EH, Doppman J \& Nieman LK. Spoiled gradient recalled acquisition in the steady state technique is superior to conventional post-contrast spin echo technique for magnetic resonance imaging detection of adrenocorticotropin-secreting pituitary tumors. Journal of Clinical Endocrinology and Metabolism 200388 1565-1569. (doi:10.1210/ jc.2002-021438)

16 Buurman H \& Saeger W. Subclinical adenomas in postmortem pituitaries: classification and correlations to clinical data. European Journal of Endocrinology $2006 \mathbf{1 5 4}$ 753-758. (doi:10.1530/eje.1.02107)

17 Mehta GU, Montgomery BK, Raghavan P, Sharma S, Nieman LK, Patronas N, Oldfield EH \& Chittiboina P. Different imaging characteristics of concurrent pituitary adenomas in a patient with Cushing's disease. Journal of Clinical Neuroscience 201522 891-894. (doi:10.1016/j.jocn.2015.01.001)

18 Arnaldi G, Angeli A, Atkinson AB, Bertagna X, Cavagnini F, Chrousos GP, Fava GA, Findling JW, Gaillard RC, Grossman AB, et al. Diagnosis and complications of Cushing's syndrome: a consensus statement. Journal of Clinical Endocrinology and Metabolism $2003 \mathbf{8 8}$ 5593-5602. (doi:10.1210/jc.2003-030871)

19 Kaltsas GA, Giannulis MG, Newell-Price JD, Dacie JE, Thakkar C, Afshar F, Monson JP, Grossman AB, Besser GM \& Trainer PJ. A critical analysis of the value of simultaneous inferior petrosal sinus sampling in Cushing's disease and the occult ectopic adrenocorticotropin syndrome. Journal of Clinical Endocrinology and Metabolism 199984 487-492. (doi:10.1210/jc.84.2.487)

20 Meier CA \& Biller BM. Clinical and biochemical evaluation of Cushing's syndrome. Endocrinology and Metabolism Clinics of North America 199726 741-762. (doi:10.1016/S0889-8529(05)70280-2)

21 Sheth SA, Mian MK, Neal J, Tritos NA, Nachtigall L, Klibanski A, Biller BM \& Sweringen B. Transphenoidal surgery for cushing disease after nondiagnostic inferior petrosal sinus sampling. Neurosurgery 201271 14-22. (doi:10.1227/NEU.0b013e31824f8e2e)

22 Yogi-Morren D, Habra MA, Faiman C, Bena J, Hatipoglu B, Kennedy L, Weil RJ, \& Hamrahian AH. Pituitary MRI findings in patients with pituitary and ectopic ACTH-dependent Cushing syndrome: does a 6-mm pituitary tumor size cut-off value exclude ectopic ACTH syndrome? Endocrine Practice 201521 1098-1103. (doi:10.4158/EP15662.OR)

23 Gold EM. The Cushing syndromes: changing views of diagnosis and treatment. Annals of Internal Medicine 197990 829-844. (doi:10.7326/0003-4819-90-5-829)

24 Boggan JE, Tyrrell JB \& Wilson CB. Transsphenoidal microsurgical management of Cushing's disease. Report of 100 cases. Journal of Neurosurgery 198359 195-200. (doi:10.3171/jns.1983.59.2.0195)

25 McCance DR, McIlrath E, McNeill A, Gordon DS, Hadden DR, Kennedy L, Sheridan B \& Atkinson AB. Bilateral inferior petrosal sinus sampling as a routine procedure in ACTH-dependent
Cushing's syndrome. Clinical Endocrinology 198930 157-166. (doi:10.1111/j.1365-2265.1989.tb03737.x)

26 Scriba PC, von Werder K, Richter J \& Schwarz K. A contribution to the clinical diagnosis of the ectopic ACTH syndrome. Klinische Wochenschrift 196846 49-51.

27 Gorden P, Becker CE, Levey GS \& Roth J. Efficacy of aminoglutethimide in the ectopic ACTH syndrome. Journal of Clinical Endocrinology and Metabolism 196828 921-923. (doi:10.1210/jcem28-6-921)

28 Brown RD, Van Loon GR, Orth DN \& Liddle GW. Cushing's disease with periodic hormonogenesis: one explanation for paradoxical response to dexamethasone. Journal of Clinical Endocrinology and Metabolism 197336 445-451. (doi:10.1210/jcem-36-3-445)

29 Corrigan DF, Schaaf M, Whaley RA, Czerwinski CL \& Earll JM. Selective venous sampling to differentiate ectopic ACTH secretion from pituitary Cushing's syndrome. New England Journal of Medicine 1977296 861-862. (doi:10.1056/NEJM197704142961508)

30 Kley HK, Stolze T \& Kruskemper HL. Jugular vein sampling of ACTH. New England Journal of Medicine 1977297 730-731. (doi:10.1056/ nejm197709292971319)

31 Wahl TO \& Kyner JL. Source of ACTH in Cushing's disease. New England Journal of Medicine 1979300 679. (doi:10.1056/ nejm197903223001218)

32 Findling JW, Aron DC, Tyrrell JB, Shinsako JH, Fitzgerald PA, Norman D, Wilson CB \& Forsham PH. Selective venous sampling for ACTH in Cushing's syndrome: differentiation between Cushing disease and the ectopic ACTH syndrome. Annals of Internal Medicine 198194 647-652. (doi:10.7326/0003-4819-94-5-647)

33 Grant SJ, Stiel JN, Sorby WA \& Henniker AJ. Venous ACTH sampling in Cushing's syndrome. Medical Journal of Australia 19837 336-337.

34 Manni A, Latshaw RF, Page R \& Santen RJ. Simultaneous bilateral venous sampling for adrenocorticotropin in pituitary-dependent Cushing's disease: evidence for lateralization of pituitary venous drainage. Journal of Clinical Endocrinology and Metabolism $1983 \mathbf{5 7}$ 1070-1073. (doi:10.1210/jcem-57-5-1070)

35 Oldfield EH, Chrousos GP, Schulte HM, Schaaf M, McKeever PE, Krudy AG, Cutler GB Jr, Loriaux DL \& Doppman JL. Preoperative lateralization of ACTH-secreting pituitary microadenomas by bilateral and simultaneous inferior petrosal venous sinus sampling. New England Journal of Medicine 1985312 100-103. (doi:10.1056/ NEJM198501103120207)

36 Landolt AM, Valavanis A, Girard J \& Eberle AN. Corticotrophinreleasing factor-test used with bilateral, simultaneous inferior petrosal sinus blood-sampling for the diagnosis of pituitarydependent Cushing's disease. Clinical Endocrinology 198625 687-696. (doi:10.1111/j.1365-2265.1986.tb03624.x)

37 Hauffa BP, Stolecke H \& Schulte HM. Cushing disease: successful preoperative lateralization of an ACTH-producing pituitary microadenoma by simultaneous bilateral inferior petrosal venous sinus sampling with corticotropin-releasing hormone stimulation. European Journal of Pediatrics 1986145 559-562. (doi:10.1007/ BF02429066)

38 Schulte HM, Allolio B, Gunther RW, Benker G, Winkelmann W, Hollmann JP, Windeck R \& Reinwein D. Simultaneous bilateral catheterization of the inferior petrosal sinus in Cushing's syndrome. ACTH determination for the diagnosis and location of the side of a hypophyseal microadenoma before and after administration of corticotropin-releasing hormone. Deutsche Medizinische Wochenschrift 1987112 1767-1771. (doi:10.1055/s-2008-1068326)

39 Oldfield EH, Doppman JL, Nieman LK, Chrousos GP, Miller DL, Katz DA, Cutler GB Jr \& Loriaux DL. Petrosal sinus sampling with and without corticotropin-releasing hormone for the differential diagnosis of Cushing's syndrome. New England Journal of Medicine 1991325 897-905. (doi:10.1056/NEJM199109263251301)

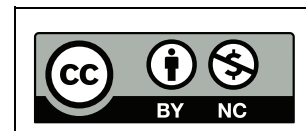

This work is licensed under a Creative Commons Attribution-NonCommercial 4.0 International License. 
40 Page RB. Directional pituitary blood flow: a microcinephotographic study. Endocrinology 1983112 157-165. (doi:10.1210/endo-112-1-157)

41 Yanovski JA, Cutler Jr GB, Doppman JL, Miller DL, Chrousos GP, Oldfield EH \& Nieman LK. The limited ability of inferior petrosal sinus sampling with corticotrophin-releasing hormone to distinguish Cushing's disease from pseudo Cushing's states or normal physiology. Journal of Clinical Endocrinology and Metabolism $19937 \mathbf{7}$ 503-509. (doi:10.1210/jc.77.2.503)

42 Mamelak AN, Dowd CF, Tyrrell JB, Mcdonald JF \& Wilson CB. Venous angiography is needed to interpret inferior petrosal sinus and cavernous sinus sampling data for lateralizing adrenocorticotropinsecreting adenomas. Journal of Clinical Endocrinology and Metabolism 199681 475-481. (doi:10.1210/jc.81.2.475)

43 Utz A \& Biller BM. The role of bilateral inferior petrosal sinus sampling in the diagnosis of Cushing's syndrome. Arquivos Brasileiros de Endocrinologia e Metabologia. 200751 1329-1338. (doi:10.1590/ s0004-27302007000800019)

44 Javorsky BR \& Findling JW. Contemporary Endocrinology: Cushing's Syndrome: Pathophysiology, Diagnosis and Treatment, pp 105-121. New York, NY, USA: Springer, 2010. (doi:10.1007/978-1-60327-449-4)

45 Findling JW \& Raff H. Cushing's syndrome: important issues in diagnosis and management. Journal of Clinical Endocrinology and Metabolism 200691 3746-3753. (doi:10.1210/jc.2006-0997)

46 Findling JW, Kehoe ME, Shaker JL \& Raff H. Routine inferior petrosal sinus sampling in the differential diagnosis of adrenocorticotropin (ACTH)-dependent Cushing's syndrome: early recognition of the occult ectopic ACTH syndrome. Journal of Clinical Endocrinology and Metabolism 199173 408-413. (doi:10.1210/jcem-73-2-408)

47 Ikeda H, Abe T \& Watanabe K. Usefulness of composite methioninepositron emission tomography/3.0-tesla magnetic resonance imaging to detect the localization and extent of early-stage Cushing adenoma. Journal of Neurosurgery 2010112 750-755. (doi:10.3171/ 2009.7.JNS09285)

48 Reimondo G, Paccotti P, Minetto M, Termine A, Stura G, Bergui M, Angeli A \& Terzolo M. The corticotrophin-releasing hormone test is the most reliable noninvasive method to differentiate pituitary from ectopic ACTH secretion in Cushing's syndrome. Clinical Endocrinology 200358 718-724. (doi:10.1046/j.13652265.2003.01776.X)

49 Yamamoto Y, Davis DH, Nippoldt TB, Young WF Jr, Huston J 3rd $\&$ Parisi JE. False-positive inferior petrosal sinus sampling in the diagnosis of Cushing's disease. Report of two cases. Journal of Neurosurgery 199583 1087-1091. (doi:10.3171/jns.1995.83.6.1087)

50 Karageorgiadis AS, Papadakis GZ, Biro J, Keil MF, Lyssikatos C, Quezado MM, Merino M, Schrump DS, Kebebew E, Patronas NJ, et al. Ectopic adrenocorticotropic hormone and corticotropin-releasing hormone co-secreting tumors in children and adolescents causing Cushing syndrome: a diagnostic dilemma and how to solve it. Journal of Clinical Endocrinology and Metabolism 2015100 141-148. (doi:10.1210/jc.2014-2945)

51 Martin NM, Dhillo WS, Banerjee A, Abdulali A, Jayasena CN, Donaldson M, Todd JF \& Meeran K Comparison of the dexamethasone-suppressed corticotropin-releasing hormone test and low-dose dexamethasone suppression test in the diagnosis of Cushing's syndrome. Journal of Clinical Endocrinology and Metabolism 200691 2582-2586. (doi:10.1210/jc.2005-2143)

52 Shi X, Sun Q, Bian L, Zhao W, Shen J, Wang W \& Ning G. Assessment of bilateral inferior petrosal sinus sampling in the diagnosis and surgical treatment of the ACTH-dependent Cushing's syndrome: a comparison with other tests. Neuro Endocrinology Letters 201132 865-873.

53 Jeffcoate W. Probability in practice in the diagnosis of Cushing's syndrome. Clinical Endocrinology 199747 271-272. (doi:10.1046/ j.1365-2265.1997.2671072.x)

54 Invitti C, Pecori Giraldi F \& Cavagnini F. Inferior petrosal sinus sampling in patients with Cushing's syndrome and contradictory responses to dynamic testing. Clinical Endocrinology 199951 255-257. (doi:10.1046/j.1365-2265.1999.00817.x)

55 Miller DL, Doppman JL \& Chang R. Anatomy of the junction of the inferior petrosal sinus and the internal jugular vein. American Journal of Neuroradiology 199314 1075-1083.

56 Doppman JL, Chang R, Oldfield EH, Chrousos G, Stratakis CA \& Nieman LK. The hypoplastic inferior petrosal sinus: a potential source of false-negative results in petrosal sampling for Cushing's disease. Journal of Clinical Endocrinology and Metabolism $19998 \mathbf{8 4}$ 533-540. (doi:10.1210/jc.84.2.533)

57 Andereggen L, Schroth G, Gralla J, Seiler R, Mariani L, Beck J, Widmer HR, Andres RH, Christ E \& Ozdoba C. Selective inferior petrosal sinus sampling without venous outflow diversion in the detection of a pituitary adenoma in Cushing's syndrome. Neuroradiology 201254 495-503. (doi:10.1007/s00234-011-0915-6)

58 Colao A, Faggiano A, Pivonello R, Pecori Giraldi F, Cavagnini F \& Lombardi G. Inferior petrosal sinus sampling in the differential diagnosis of Cushing's syndrome: results of an Italian multicenter study. European Journal of Endocrinology 2001144 499-507. (doi:10.1530/eje.0.1440499)

59 Tabarin A, Greselle JF, San-Galli F, Leprat F, Caille JM, Latapie JL, Guerin J \& Roger P. Usefulness of the corticotropin-releasing hormone test during bilateral inferior petrosal sinus sampling for the diagnosis of Cushing's disease. Journal of Clinical Endocrinology and Metabolism 199173 53-59. (doi:10.1210/jcem-73-1-53)

60 Lopez J, Barcelò B, Lucas T, Salame F, Alameda C, Boronat M, Salto L \& Estrada J. Petrosal sinus sampling for diagnosis of Cushing's disease: evidence of false negative results. Clinical Endocrinology 1996 45 147-156. (doi:10.1046/j.1365-2265.1996.d01-1550.x)

61 Heppner C, Becker K, Saeger W, Gunther RW, Allolio B, Krone W \& Winkelmann W. Occult eutopic Cushing's syndrome-failure of simultaneous bilateral petrosal sinus sampling to diagnose pituitarydependent Cushing's syndrome. European Journal of Endocrinology 1997137 74-78. (doi:10.1530/eje.0.1370074)

62 Bonelli FS, Huston J, Carpenter PC, Erickson D, Young WFJ \& Meyer FB. Adrenocorticotropic hormone-dependent Cushing's syndrome: sensitivity and specificity of inferior petrosal sinus sampling. American Journal of Neuroradiology 200021 690-696.

63 Swearingen B, Katznelson L, Miller K, Grinspoon S, Waltman A, Dorer DJ, Klibanski A \& Biller BM. Diagnostic errors after inferior petrosal sinus sampling. Journal of Clinical Endocrinology and Metabolism 200489 3752-3763. (doi:10.1210/jc.2003-032249)

64 Zarrilli L, Colao A, Merola B, La Tessa G, Spaziante R, Tripodi FS, Di Sarno A, Marzano LA \& Lombardi G. Corticotropin-releasing hormone test: improvement of the diagnostic accuracy of simultaneous and bilateral inferior petrosal sinus sampling in patients with Cushing syndrome. World Journal of Surgery 199519 150-153. (doi:10.1007/BF00317003)

65 Jehle S, Walsh JE, Freda PU \& Post KD. Selective use of bilateral inferior petrosal sinus sampling in patients with adrenocorticotropindependent Cushing's syndrome prior to transsphenoidal surgery. Journal of Clinical Endocrinology and Metabolism 200893 4624-4632. (doi:10.1210/jc.2008-0979)

66 Grant P, Dworakowska D \& Carroll P. Maximizing the accuracy of Inferior petrosal sinus sampling: validation of the use of Prolactin as a marker of pituitary venous effluent in the diagnosis of Cushing's disease. Clinical Endocrinology 201276 555-559. (doi:10.1111/j.13652265.2011.04257.x)

67 Deipolyi A, Bailin A, Joshua A Hirsch, Walker TG \& Oklu R. Bilateral inferior petrosal sinus sampling: experience in 327 patients. Journal of Neurointerventional Surgery $2016 \mathbf{1 5}$ neurintsurg-2015-012164. (doi:10.1136/neurointsurg-2015-012164)

68 Young J, Deneux C, Grino M, Oliver C, Chanson P \& Schaison G. Pitfall of petrosal sinus sampling in a Cushing's syndrome secondary to ectopic adrenocorticotropin-corticotropin releasing hormone 
(ACTH-CRH) secretion. Journal of Clinical Endocrinology and Metabolism 199883 305-308. (doi:10.1210/jc.83.2.305)

69 Ilias I, Torpy DJ, Pacak K, Mullen N, Wesley RA \& Nieman LK. Cushing's syndrome due to ectopic corticotropin secretion: twenty years' experience at the National Institutes of Health. Journal of Clinical Endocrinology and Metabolism 200590 4955-4962. (doi:10.1210/jc.2004-2527)

70 Burman P, Lethagen A, Ivancev K, Johansson L \& Sundin A. Dual bronchial carcinoids and Cushing's syndrome with a paradoxical response to dexamethasone and a false positive outcome of inferior petrosal sinus sampling. European Journal of Endocrinology 2008159 483-488. (doi:10.1530/EJE-08-0385)

71 Al-Gahtany M, Bilbao J, Kovacs K, Horvath E \& Smyth HS. Juxtaposition of an ectopic corticotroph adenoma of the sphenoid sinus with orthotopic intrasellar corticotroph hyperplasia in a patient with Cushing disease. Case report. Journal of Neurosurgery 200398 891-896. (doi:10.3171/jns.2003.98.4.0891)

72 McNally PG, Bolia A, Absalom SR, Falconer-Smith J \& Howlett TA. Preliminary observations using endocrine markers of pituitary venous dilution during bilateral simultaneous inferior petrosal sinus catheterization in Cushing's syndrome: is combined CRF and TRH stimulation of value? Clinical Endocrinology 199339 681-686. (doi:10.1111/j.1365-2265.1993.tb02427.x)

73 Findling JW, Kehoe ME \& Raff H. Identification of patients with Cushing's disease with negative pituitary adrenocorticotropin gradients during inferior petrosal sinus sampling: prolactin as an index of pituitary venous effluent. Journal of Clinical Endocrinology and Metabolism 200489 6005-6009. (doi:10.1210/jc.2004-1378)

74 Sharma ST, Raff H \& Nieman LK. Prolactin as a marker of successful catheterization during IPSS in patients with ACTH-dependent Cushing's syndrome. Journal of Clinical Endocrinology and Metabolism 201196 3687-3694. (doi:10.1210/jc.2011-2149)

75 Mulligan GB, Eray E, Faiman C, Gupta M, Pineyro MM, Makdissi A, Suh JH, Masaryk TJ, Prayson R, Weil RJ, et al. Reduction of false-negative results in inferior petrosal sinus sampling with simultaneous prolactin and corticotropin measurement. Endocrine Practice 201117 33-40. (doi:10.4158/EP10067.OR)

76 Qiao X, Ye H, Zhang X, Zhao W, Zhang S, Lu B, Wang X, Zhang Z, $\mathrm{Wu} \mathrm{X}, \mathrm{He} \mathrm{M}$, et al. The value of prolactin in inferior petrosal sinus sampling with desmopressin stimulation in Cushing's disease. Endocrine 201548 644-652. (doi:10.1007/s12020-014-0338-3)

77 Arlt W, Dahia PLM, Callies F, Nordmeyer JP, Allolio B, Grossman AB $\&$ Reincke M. Ectopic ACTH production by a bronchial carcinoid tumour to desmopressin in vivo and in vitro. Clinical Endocrinology 199747 623-627. (doi:10.1046/j.1365-2265.1997.3091129.x)

78 Tsagarakis S, Tsigos C, Vasiliou V, Tsiotra P, Kaskarelis J, Sotiropoulou C, Raptis SA \& Thalassinos N. The desmopressin and combined CRH-desmopressin tests in the differential diagnosis of ACTH-dependent Cushing's syndrome: constraints imposed by the expression of V2 vasopressin receptors in tumors with ectopic ACTH secretion. Journal of Clinical Endocrinology and Metabolism 200287 1646-1653. (doi:10.1210/jc.87.4.1646)

79 Tsagarakis S, Vassiliadi D, Kaskarelis IS, Komninos J, Souvatzoglou E $\&$ Thalassinos N. The application of the combined corticotropinreleasing hormone plus desmopressin stimulation during petrosal sinus sampling is both sensitive and specific in differentiating patients with Cushing's disease from patients with the occult ectopic adrenocorticotropin syndrome. Journal of Clinical Endocrinology and Metabolism 200792 2080-2086. (doi:10.1210/jc.2006-2691)

80 Castinetti F, Morange I, Dufour H, Jaquet P, Conte-Devolx B Girard N \& Brue T. Desmopressin test during petrosal sinus sampling: a valuable tool to discriminate pituitary or ectopic ACTHdependent Cushing's syndrome. European Journal of Endocrinology 2007157 271-277. (doi:10.1530/EJE-07-0215)

81 Machado MC, de Sa SV, Domenice S, Fragoso MC, Puglia P Jr, Pereira MA, de Mendonca BB \& Salgado LR. The role of desmopressin in bilateral and simultaneous inferior petrosal sinus sampling for differential diagnosis of ACTH-dependent Cushing's syndrome. Clinical Endocrinology 200766 136-142. (doi:10.1111/j.13652265.2006.02700.x)

82 Deipolyi AR, Hirsch JA \& Oklu R. Bilateral inferior petrosal sinus sampling with desmopressin. Journal of Neurointerventional Surgery 20135 487-488. (doi:10.1136/neurintsurg-2012-010437)

83 Vignati F, Berselli ME, Scialfa G, Boccardi E \& Loli P. Bilateral and simultaneous venous sampling of inferior petrosal sinuses for ACTH and PRL determination: preoperative localization of ACTH-secreting microadenomas. Journal of Endocrinological Investigation 198912 235-238. (doi:10.1007/BF03349972)

84 Landolt AM, Schubiger O, Maurer R \& Girard J. The value of inferior petrosal sinus sampling in diagnosis and treatment of Cushing's disease. Clinical Endocrinology 199440 485-492. (doi:10.1111/j.1365-2265.1994.tb02487.x)

85 Snow RB, Patterson RH Jr, Horwith M, Saint Louis L \& Fraser RA. Usefulness of preoperative inferior petrosal vein sampling in Cushing's disease. Surgical Neurology 198829 17-21. (doi:10.1016/0090-3019(88)90117-6)

86 Lin LY, Teng MM, Huang CI, Ma WY, Lin LY, Teng MM, Huang CI, Ma WY, Wang KL, Lin HD \& Won JG. Assessment of bilateral inferior petrosal sinus sampling (BIPSS) in the diagnosis of Cushing's disease. Journal of the Chinese Medical Association 200770 4-10. (doi:10.1016/ S1726-4901(09)70293-X)

87 Booth Gl, Redelmeier DA, Grosman H, Kovacs K, Smyth HS \& Ezzat S. Improved diagnostic accuracy of inferior petrosal sinus sampling over imaging for localizing pituitary pathology in patients with Cushing's disease. Journal of Clinical Endocrinology and Metabolism 199883 2291-2295. (doi:10.1210/jc.83.7.2291)

88 Shi X, Sun Q, Bian L, Zhao W, Shen J, Wang W \& Ning G Assessment of bilateral inferior petrosal sinus sampling in the diagnosis and surgical treatment of the ACTH-dependent Cushing's syndrome: a comparison with other tests. Neuro Endocrinology Letters 201132 865-873.

89 Potts MB, Shah JK, Molinaro AM, Blevins LS, Tyrrell JB, Kunwar S, Dowd CF, Hetts SW \& Aghi MK. Cavernous and inferior petrosal sinus sampling and dynamic magnetic resonance imaging in the preoperative evaluation of Cushing's disease. Journal of Neurooncology 2014116 593-600. (doi:10.1007/s11060-013-1342-9)

90 Miller DL, Doppman JL, Nieman LK, Cutler Jr GB, Chrousos G, Loriaux DL \& Oldfield EH. Petrosal sinus sampling: discordant lateralization of ACTH- secreting pituitary microadenomas before and after stimulation with corticotropin-releasing hormone. Radiology 1990176 429-431. (doi:10.1148/radiology.176.2.2164235)

91 de Herder WW, Uitterlinden P, Pieterman H, Tanghe HL, Kwekkeboom DJ, Pols HA, Singh R, van de Berge JH \& Lamberts SW. Pituitary tumor localization in patients with Cushing's disease by magnetic resonance imaging. Is there a place for petrosal sinus sampling? Clinical Endocrinology 199440 87-92. (doi:10.1111/j.1365-2265.1994.tb02448.x)

92 Liu C, Lo JC, Dowd CF, Wilson CB, Kunwar S, Aron DC \& Tyrrell JB. Cavernous and inferior petrosal sinus sampling in the evaluation of ACTH-dependent Cushing's syndrome. Clinical Endocrinology 2004 61 478-486. (doi:10.1111/j.1365-2265.2004.02115.x)

93 Zovickian J, Oldfield EH, Doppman JL, Cutler GR \& Loriaux DL. Usefulness of inferior petrosal sinus venous endocrine markers for Cushing's disease. Journal of Neurosurgery 198868 205-210. (doi:10.3171/jns.1988.68.2.0205)

94 Crock PA, Pestell RG, Calenti AJ, Gilford EJ, Henderson JK, Best JD \& Alford FP. Multiple pituitary hormone gradients from inferior petrosal sinus sampling in Cushing's disease. Acta Endocrinologica 1988119 75-80. (doi:10.1530/acta.0.1190075)

95 Colao A, Merola B, Tripodi FS, Di Sarno A, Esposito V, Marzullo P, La Tessa G, Spaziante R \& Lombardi G. Simultaneous and bilateral inferior petrosal sinus sampling for the diagnosis of Cushing's 
syndrome: comparison of multihormonal assay, baseline multiple sampling and ACTH-releasing hormone test. Hormone Research 1993 40 209-16. (doi:10.1159/000183797)

96 Schulte HM, Allolio B, Gunther RW, Benker G, Winkelmann W, Ohnhaus EE \& Reinwein D. Selective bilateral and simultaneous catheterization of the inferior petrosal sinus: CRF stimulates prolactin secretion from ACTH-producing microadenomas in Cushing's disease. Clinical Endocrinology 198828 289-295. (doi:10.1111/j.1365-2265.1988.tb01215.x)

97 Allolio B, Guhnther RW, Benker G, Reinwein D, Winkelmann W \& Schulte HM. A multihormonal response to corticotrophin-releasing hormone in inferior petrosal sinus blood of patients with Cushing's disease. Journal of Clinical Endocrinology and Metabolism $1990 \mathbf{7 1}$ 1195-1201. (doi:10.1210/jcem-71-5-1195)

98 Colao A, Merola B, Spaziante R, La Tessa G, Boudouresque F, Oliver C $\&$ Lombardi G. Adrenocorticotropic hormone and endorphin concentrations in the inferior petrosal sinuses in Cushing's disease and other pituitary diseases. Journal of Endocrinological Investigation 199215 807-813. (doi:10.1007/BF03348809)

99 Loli P, Boccardi E, Branca V, Bramerio M, Barberis M, Losa M, Terreni MT, Lodrini S, Pollo B \& Vignati F. Growth hormone and prolactin responses to corticotrophin-releasing-hormone in patients with Cushing's disease: a paracrine action of the adenomatous corticotroph cells? Clinical Endocrinology 199849 433-439. (doi:10.1046/j.1365-2265.1998.00531.x)

100 Daousi C, Nixon T, Javadpour M, Hayden K \& MacFarlane IA. Inferior petrosal sinus ACTH and prolactin responses to CRH in ACTH-dependent Cushing's syndrome: a single centre experience from the United Kingdom. Pituitary 201013 95-104. (doi:10.1007/ s11102-009-0200-4)

101 Mulligan GB, Faiman C, Gupta M, Kennedy L, Hatipoglu B, Hui F Weil RJ \& Hamrahian AH. Prolactin measurement during inferior petrosal sinus sampling improves the localization of pituitary adenomas in Cushing's disease. Clinical Endocrinology 201277 268-274. (doi:10.1111/j.1365-2265.2012.04339.x)

102 Wind JJ, Lonser RR, Nieman LK, DeVroom HL, Chang R \& Oldfiel EH. The lateralization accuracy of inferior petrosal sinus sampling in 501 patients with Cushing's disease. Journal of Clinical Endocrinology and Metabolism 201398 2285-2293. (doi:10.1210/jc.2012-3943)

103 Lienhardt A, Grossman AB, Dacie JE, Evanson J, Huebner A, Afshar F, Plowman PN, Besser GM \& Savage MO. Relative contributions of inferior petrosal sinus sampling and pituitary imaging in the investigation of children and adolescents with ACTH-dependent Cushing's syndrome. Journal of Clinical Endocrinology and Metabolism 200186 5711-5714. (doi:10.1210/jc.86.12.5711)

104 Magiakou MA, Mastorakos G, Oldfield EH, Gomez MT, Doppman JL, Cutler GB, Nieman LK \& Chrousos GP. Cushing's syndrome in children and adolescents. New England Journal of Medicine 1994331 629-636. (doi:10.1056/NEJM199409083311002)

105 Batista D, Gennari M, Riar J, Chang R, Keil MF, Oldfield EH $\&$ Stratakis CA. An assessment of petrosal sinus sampling for localization of pituitary microadenomas in children with Cushing disease. Journal of Clinical Endocrinology and Metabolism 200691 221-224. (doi:10.1210/jc.2005-1096)

106 Miller DL, Doppman JL, Peterman SB, Nieman LK, Oldfield EH \& Chang R. Neurologic complications of petrosal sinus sampling. Radiology 1992185 143-147. (doi:10.1148/radiology.185.1.1523298)

107 Sturrock N \& Jeffcoate W. A neurological complication of inferior petrosal sinus sampling during investigation for Cushing's disease: a case report. Journal of Neurology, Neurosurgery, and Psychiatry 199762 527-528. (doi:10.1136/jnnp.62.5.527)
108 Gandhi CD, Meyer SA, Patel AB, Johnson DM \& Post KD. Neurologic complications of inferior petrosal sinus sampling. American Journal of Neuroradiology 200829 760-765. (doi:10.3174/ajnr.A0930)

109 Bonelli FS, Huston J, Meyer FB \& Carpenter PC. Venous subarachnoid hemorrhage after inferior petrosal sinus sampling for adrenocorticotropic hormone. American Journal of Neuroradiology 199920 306-307.

110 Diez J \& Iglesias P. Pulmonary thromboembolism after inferior petrosal sinus sampling in Cushing's syndrome. Clinical Endocrinology 199746777.

111 Lefournier V, Gatta B, Martinie M, Vasdev A, Tabarin A, Bessou P, Berge J, Bachelot I \& Chabre O. One transient neurological complication (sixth nerve palsy) in 166 consecutive inferior petrosal sinus samplings for the etiological diagnosis of Cushing's syndrome. Journal of Clinical Endocrinology and Metabolism 199984 3401-3402. (doi:10.1210/jc.84.9.3401)

112 Doppman JL, Oldfield EH \& Nieman LK. Bilateral sampling of the internal jugular vein to distinguish between mechanisms of adrenocorticotropic hormone-dependent Cushing syndrome. Annals of Internal Medicine 1998128 33-36. (doi:10.7326/0003-4819-128-1199801010-00006)

113 Erickson D, Huston J 3rd, Young WF Jr, Carpenter PC, Wermers RA, Bonelli FS \& Powell CC. Internal jugular vein sampling in adrenocorticotropic hormone-dependent Cushing's syndrome: a comparison with inferior petrosal sinus sampling. Clinical Endocrinology 200460 413-419. (doi:10.1111/j.1365-2265.2004.01990.x)

114 Ilias I, Chang R, Pacak K, Oldfield EH, Wesley R, Doppman J \& Nieman LK. Jugular venous sampling: an alternative to petrosal sinus sampling for the diagnostic evaluation of adrenocorticotropic hormonedependent Cushing's syndrome. Journal of Clinical Endocrinology and Metabolism 200489 3795-3800. (doi:10.1210/jc.2003-032014)

115 Teramoto A, Nemoto S, Takakura K, Sasaki Y \& Machida T. Selective venous sampling directly from cavernous sinus in Cushing's syndrome. Journal of Clinical Endocrinology and Metabolism 199376 637-641. (doi:10.1210/jc.76.3.637)

116 Flitsch J, Lüdecke DK, Knappe UJ \& Grzyska U. Cavernous sinus sampling in selected cases of Cushing's disease. Experimental and Clinical Endocrinology \& Diabetes $2002110329-335$. (doi:10.1055/s-2002-34989)

117 Gazioglu N, Ulu MO, Ozlen F, Albayram S, Islak C, Kocer N, Oz B, Tanriover N, Yetkin DO, Gundogdu S, et al. Management of Cushing's disease using cavernous sinus sampling: effectiveness in tumor lateralization. Clinical Neurology and Neurosurgery 2008110 333-338. (doi:10.1016/j.clineuro.2007.11.008)

118 Burkhardt T, Flitsch J, van Leyen P, Sauer N, Aberle J, Grzyska U \& Lüdecke DK. Cavernous sinus sampling in patients with Cushing's disease. Neurosurgical Focus 201538 E6. (doi:10.3171/2014.10. FOCUS14687)

119 Doppman JL, Nieman LK, Chang R, Yanovski J, Cutler GB Jr, Chrousos GP \& Oldfield EH. Selective venous sampling from the cavernous sinuses is not a more reliable technique than sampling from the inferior petrosal sinuses in Cushing's disease. Journal of Clinical Endocrinology and Metabolism 199580 2485-2489. (doi:10.1210/jc.80.8.2485)

120 Lefournier V, Martinie M, Vasdev A, Bessou P, Passagia JG, LabatMoleur F, Sturm N, Bosson JL, Bachelot I \& Chabre O. Accuracy of bilateral inferior petrosal or cavernous sinuses sampling in predicting the lateralization of Cushing's disease pituitary microadenoma: influence of catheter position and anatomy of venous drainage. Journal of Clinical Endocrinology and Metabolism 200388 196-203. (doi:10.1210/jc.2002-020374)

Received in final form 20 June 2016

Accepted 27 June 2016

Accepted Preprint published online 27 June 2016

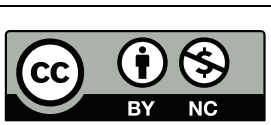

